\title{
Effects of Acid Stress on Vibrio parahaemolyticus Survival and Cytotoxicity
}

\author{
P. S. MARIE YEUNG AND KATHRYN J. BOOR* \\ Department of Food Science, Cornell University, Ithaca, New York 14853, USA \\ MS 03-546: Received 25 November 2003/Accepted 2 February 2004
}

\begin{abstract}
For several foodborne bacterial pathogens, an acid tolerance response appears to be an important strategy for counteracting acid stress imposed either during food processing or by the human host. The acid tolerance response enhances bacterial survival of lethal acid challenge following prior exposure to sublethal acidic conditions. Previous studies have revealed relationships between a foodborne pathogen's ability to survive acid challenge and its infectious dose. Vibrio parahaemolyticus is capable of causing gastroenteritis when sufficient cells of pathogenic strains are consumed. This study was designed to characterize acid sensitivities and to compare the effects of sublethal acid exposure (adaptation) on survival capabilities and cytotoxicities of different $V$. parahaemolyticus strains. Survival of acid challenge by stationary-phase cells differed by up to $3 \log \mathrm{CFU} / \mathrm{ml}$ among the 25 isolates tested. No differences in acid resistance were found between strains when they were grouped by source (clinical isolates versus those obtained from food). Survival at pH 3.6 for log-phase cells that had been previously exposed to sublethal acidic conditions ( $\mathrm{pH} 5.5$ ) was enhanced compared with that for cells not previously exposed to $\mathrm{pH}$ 5.5. However, for stationary-phase cells, exposure to $\mathrm{pH} 5.5$ impaired both subsequent survival at $\mathrm{pH} 3.6$ and cytotoxicity to human epithelial cells. Relative cytotoxicities of nonadapted stationary-phase cells were 1.2- to 4.8 -fold higher than those of adapted cells. Sublethal acid exposure appears to impose measurable growth phase-dependent effects on subsequent lethal acid challenge survival and cytotoxicity of $V$. parahaemolyticus.
\end{abstract}

Though genetically and phenotypically diverse, foodborne pathogens encounter similar stresses, such as exposure to acidic conditions, that are imposed by food processing procedures and by their human hosts. The acid tolerance response (ATR) has been recognized as an important strategy employed by foodborne pathogens to counteract acid stress. Various pathogens, including Salmonella Typhimurium, Listeria monocytogenes, and Escherichia coli O157:H7, have enhanced survival capabilities during exposure to a lethal acid challenge when these pathogens have had prior exposure to sublethal acidic conditions $(9,15$, 36). Previous studies with Vibrio cholerae and L. monocytogenes have revealed that ATR also contributes to enhanced bacterial virulence in mouse models $(31,36)$. Thus, in addition to enhancing bacterial survival, ATR also may influence bacterial pathogenesis.

Vibrio parahaemolyticus, a gram-negative microorganism found in the marine environment, is capable of causing gastroenteritis; typical clinical signs include diarrhea, abdominal pain, nausea, vomiting, headache, fever, and chills. Individual factors that have been associated with virulence in $V$. parahaemolyticus include a thermostable direct hemolysin, a thermostable direct hemolysin-related hemolysin, and urea hydrolysis $(19,20,23,33,34)$. Although an ATR has been reported previously for at least two $V$. parahaemolyticus strains $(24,43)$, specific mechanisms that may contribute to the ability of pathogenic $V$. parahae-

\footnotetext{
* Author for correspondence. Tel: 607-255-3111; Fax: 607-254-4868;
} E-mail: kjb4@cornell.edu. molyticus strains to endure the acidic environment of the human stomach and to subsequently mount an infection are unknown. To provide an overview of the acid resistance characteristics of $V$. parahaemolyticus, the objectives of this study were (i) to determine the innate acid sensitivities of multiple, diverse $V$. parahaemolyticus isolates, (ii) to determine for multiple strains the effect of prior exposure to sublethal acidic conditions (i.e., acid adaptation) on subsequent strain survival at a lower $\mathrm{pH}$, and (iii) to determine the effect of acid adaptation on subsequent $V$. parahaemolyticus strain cytotoxicity in HeLa cells. We also evaluated the relative acid sensitivities among $V$. parahaemolyticus isolates classified according to isolation source.

\section{MATERIALS AND METHODS}

Bacterial isolates. Isolates used in this study were provided by the U.S. Food and Drug Administration (Table 1). Serotypes were determined previously by the Centers for Disease Control and Prevention. Upon receipt, all isolates were streaked for isolation of single colonies on tryptic soy agar (Difco Laboratories, Becton Dickinson, Sparks, Md.) supplemented with $2 \% \mathrm{NaCl}$ (TSAS). Isolates were stored in tryptic soy broth supplemented with $2 \% \mathrm{NaCl}$ (TSBS) and $20 \%$ glycerol at $-80^{\circ} \mathrm{C}$. Isolates were subcultured on TSAS at least once before each experiment.

Acid sensitivity assays. To evaluate strain sensitivity to acid, growth kinetics and survival of each strain were measured under various conditions. Overnight cultures $\left(37^{\circ} \mathrm{C}, 12\right.$ to $\left.16 \mathrm{~h}, 250 \mathrm{rpm}\right)$ were used to inoculate TSBS ( $1 \%$ inoculum, vol/vol) that had been adjusted with $6 \mathrm{~N} \mathrm{HCl}$ to $\mathrm{pH} 7.2,6.5,5.5$, or 4.2. Growth kinetics were determined by monitoring the optical density at 600 $\mathrm{nm}\left(\mathrm{OD}_{600}\right)$ for each strain grown in microtiter plate wells. The 
TABLE 1. Vibrio parahaemolyticus isolates used in this study and their innate acid sensitivities

\begin{tabular}{|c|c|c|c|c|c|c|c|}
\hline \multirow[b]{2}{*}{ Laboratory no. } & \multirow[b]{2}{*}{ FDA no. } & \multirow[b]{2}{*}{ Serotype } & \multirow[b]{2}{*}{ Source } & \multirow[b]{2}{*}{ Place of isolation } & \multirow[b]{2}{*}{ Year of isolation } & \multicolumn{2}{|c|}{ Acid sensitivity $^{a}$} \\
\hline & & & & & & Mean \pm SE & $n$ \\
\hline FSL-Y1-003 & T-3980 & $\mathrm{O} 4: \mathrm{K} 13$ & Clinical & Japan & Unknown & $2.3 \pm 0.8$ & 4 \\
\hline FSL-Y1-010 & T-3979 & O5:K15 & Clinical & Japan & Unknown & $5.4 \pm 0.5^{b}$ & 5 \\
\hline FSL-Y1-012 & 48432 & $\mathrm{O} 4: \mathrm{K} 12$ & Clinical & Washington & 1991 & $3.3 \pm 0.5$ & 4 \\
\hline FSL-Y1-013 & 47978 & O6:K18 & Clinical & Washington & 1991 & $3.1 \pm 1.0^{c}$ & 4 \\
\hline FSL-Y1-014 & AN-5034 & $\mathrm{O} 4: \mathrm{K} 68^{d}$ & Clinical & Bangladesh & 1996 & $1.9 \pm 0.7$ & 4 \\
\hline FSL-Y1-015 & AN-16000 & O1:KUT ${ }^{\text {de }}$ & Clinical & Bangladesh & 1998 & $3.5 \pm 0.7^{c}$ & 4 \\
\hline FSL-Y1-016 & TX-2103 & $\mathrm{O} 3: \mathrm{K} 6$ & Clinical & Texas & 1998 & $2.5 \pm 0.6$ & 4 \\
\hline FSL-Y1-017 & NY-3064 & O3:K6 & Clinical & New York & 1998 & $2.8 \pm 0.5$ & 3 \\
\hline FSL-Y1-021 & U-5474 & Old O3:K6 ${ }^{f}$ & Clinical & Bangladesh & 1980 & $3.6 \pm 0.8$ & 3 \\
\hline FSL-Y1-023 & VP86 & O3:K6 & Clinical & Calcutta & 1996 & $3.8 \pm 0.3$ & 4 \\
\hline FSL-Y1-024 & VP199 & O3:K6 & Clinical & Calcutta & 1997 & $4.7 \pm 1.1^{b}$ & 3 \\
\hline FSL-Y1-025 & VP208 & O3:K6 & Clinical & Calcutta & 1997 & $2.4 \pm 0.3$ & 4 \\
\hline FSL-Y1-026 & VP155 & $\mathrm{O} 3: \mathrm{K} 6$ & Clinical & Calcutta & 1996 & $4.0 \pm 1.0^{c}$ & 5 \\
\hline FSL-Y1-046 & BAC-98-03255 & O3:K6 & Clinical & New York & Unknown & $2.2 \pm 0.8$ & 5 \\
\hline FSL-Y1-004 & CRAB & Unknown & Food & Washington & 1972 & $2.9 \pm 1.2$ & 5 \\
\hline FSL-Y1-001 & $92000713(1)$ & O8 & Food (clam) & Unknown & 1992 & $3.2 \pm 0.5$ & 4 \\
\hline FSL-Y1-002 & NY477 & $\mathrm{O} 4: \mathrm{K} 8$ & Food (oyster) & New York & 1977 & $3.4 \pm 1.1$ & 4 \\
\hline FSL-Y1-005 & $5 \mathrm{C}-1 \mathrm{C}$ & $\mathrm{O} 1$ & Food (oyster) & Washington & 1988 & $4.3 \pm 1.0^{c}$ & 3 \\
\hline FSL-Y1-006 & M350A & O5 & Food (oyster) & Washington & 1994 & $3.4 \pm 0.6$ & 5 \\
\hline FSL-Y1-011 & 8332924 & O1:K56 & Food (oyster) & Gulf & 1983 & $4.0 \pm 0.5$ & 3 \\
\hline FSL-Y1-059 & $98-792-807$ (27) & O8:K74 & Food (oyster) & Galveston Bay & 1998 & $4.0 \pm 1.0^{c}$ & 7 \\
\hline FSL-Y1-068 & DI-A6-031699 & $\mathrm{O} 4: \mathrm{K} 9$ & Food (oyster) & Alabama & Unknown & $5.2 \pm 1.0^{b}$ & 3 \\
\hline FSL-Y1-069 & DI-B11-031699 & $\mathrm{O} 4: \mathrm{K} 22$ & Food (oyster) & Alabama & Unknown & $3.1 \pm 0.9$ & 3 \\
\hline FSL-Y 1-073 & DI-F8-031699 & O11:KUT & Food (oyster) & Alabama & Unknown & $3.0 \pm 0.5$ & 3 \\
\hline FSL-Y1-081 & DI-A6-020800 & O11:K61 & Food (oyster) & Alabama & Unknown & $3.8 \pm 0.9$ & 3 \\
\hline
\end{tabular}

${ }^{a} \mathrm{Log} \mathrm{CFU} / \mathrm{ml}$ reduction (mean $\pm \mathrm{SE}$ ) of stationary-phase cells following exposure to TSBS pH 3.6 adjusted with $6 \mathrm{~N} \mathrm{HCl}$ at $37^{\circ} \mathrm{C}$ for $30 \min . n=$ the number of independent experiments conducted for each isolate.

${ }^{b} \mathrm{CFU} / \mathrm{ml}$ fell below the detection limit of the assay $(300 \mathrm{CFU} / \mathrm{ml})$ in two independent experiments for these strains.

${ }^{c} \mathrm{CFU} / \mathrm{ml}$ fell below the detection limit of the assay $(300 \mathrm{CFU} / \mathrm{ml})$ in one experiment for these strains.

${ }^{d}$ Strains deemed genetically similar to O3:K6 strains by arbitrarily primed PCR, ribotypes, and pulsed-field gel electrophoresis pattern analyses $(10,30)$.

${ }^{e} \mathrm{UT}$, untypeable.

${ }^{f} \mathrm{O} 3: \mathrm{K} 6$ strain isolated before 1996 that is genetically different from the O3:K6 strains isolated after 1996.

microtiter plates were incubated statically at $37^{\circ} \mathrm{C}$ in a microplate analyzer (Fusion Universal, Packard Instrument Co., Meriden, Conn.). Readings were taken every $10 \mathrm{~min}$ for $\sim 5 \mathrm{~h}$.

To determine bacterial survival following acid exposure, bacterial colonies were enumerated by standard procedures following exposure to acidic conditions. Stationary-phase cells were obtained by growing $V$. parahaemolyticus cells to a mean ( \pm standard error [SE]) $\mathrm{OD}_{600}$ of $1.1 \pm 0.1$. Culture samples were centrifuged, and the cell pellets were resuspended in TSBS with $\mathrm{pH}$ levels ranging from 3.0 to 6.5 (adjusted with $6 \mathrm{~N} \mathrm{HCl}$ ) and incubated at $37^{\circ} \mathrm{C}$ for $30 \mathrm{~min}$ or for $1 \mathrm{~h}$ with shaking at $250 \mathrm{rpm}$. Based on results from these preliminary trials, $\mathrm{pH} 3.6$ was selected for subsequent lethal acid challenge conditions for all 25 strains. Stationary-phase cultures were serially diluted in phosphate-buffered saline, and $0.1 \mathrm{ml}$ of the appropriate dilution was spread plated onto TSAS plates. Plates were incubated at $37^{\circ} \mathrm{C}$ for 16 to $18 \mathrm{~h}$, and then colonies were counted. Only data from plates bearing 30 to 300 colonies were used in the calculations, hence the effective lower limit for detection of assay survivors was 300 $\mathrm{CFU} / \mathrm{ml}$. To enable calculations and statistical analyses, when the number of colonies present on a plate from the lowest dilution was $<30$, we used $300 \mathrm{CFU} / \mathrm{ml}$ as the number of survivors present after acid challenge. Experiments were conducted at least three times for each isolate.
ATR assays. To determine the effect of ATR on subsequent survival, log- and stationary-phase $V$. parahaemolyticus cells were subjected to an adaptation treatment (TSBS, pH $5.5 \pm 0.1$ for 1 $\mathrm{h}$ at $37^{\circ} \mathrm{C}$ ) prior to exposure to an acid challenge (TSBS, pH 3.6 \pm 0.1 for $30 \mathrm{~min}$ at $37^{\circ} \mathrm{C}$ ). Log-phase cells were obtained by growing $V$. parahaemolyticus cells to an $\mathrm{OD}_{600}$ of $0.4 \pm 0.05$. Stationary-phase cells also were obtained. To control for possible effects of the addition of fresh medium during the acid adaptation procedure, nonadapted cells were prepared in parallel with the adapted cells by incubating log- or stationary-phase cells in TSBS at $\mathrm{pH} 7.2$ rather than at $\mathrm{pH} 5.5$ for $1 \mathrm{~h}$ prior to acid challenge. To monitor viability of nonstressed cells throughout the experiment, additional controls were prepared by incubating both adapted and nonadapted cells in TSBS at pH 7.2 in parallel with those incubated at $\mathrm{pH} 3.6$ during the acid challenge procedure. A schematic representation of the experimental procedure is shown in Figure 1. Samples were taken (Fig. 1) to count the CFU present. At least two independent experiments were conducted on each isolate. For each sample, survival percentage $=100 \times$ (colony counts at 30 min after $\mathrm{pH} 3.6$ acid challenge/colony counts obtained immediately following exposure to $\mathrm{pH} 3.6$ ).

Cytotoxicity assays. To assess the relationship between ATR and virulence-associated characteristics, we used a tissue culture 
FIGURE 1. Experimental procedure to measure survival of $\mathrm{V}$. parahaemolyticus cells following acid adaptation.

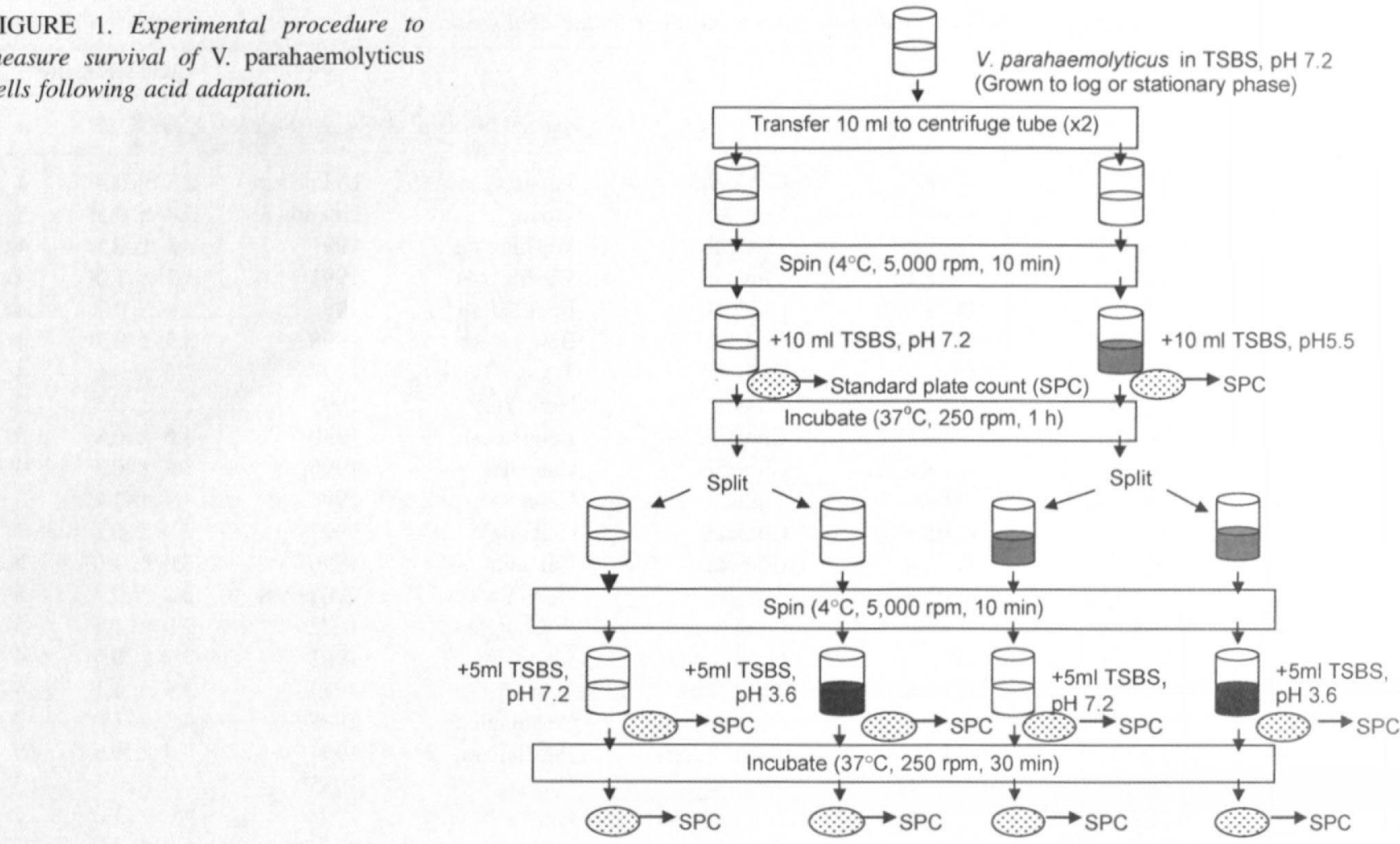

V. parahaemolyticus in TSBS, $\mathrm{pH} 7.2$ (Grown to log or stationary phase)

model to measure HeLa cell cytotoxicity induced by acid-adapted or nonadapted $V$. parahaemolyticus cells harvested in stationary phase. Two tubes of $500-\mu l$ aliquots of $V$. parahaemolyticus cultures (typically $8 \times 10^{8}$ to $2 \times 10^{9} \mathrm{CFU} / \mathrm{ml}$ ) were centrifuged at $13,000 \mathrm{rpm}(17,900 \times \mathrm{g})$ for $5 \mathrm{~min}$ and resuspended in $500 \mu \mathrm{l}$ of TSBS pH 7.2 and TSBS pH 5.5, respectively. After incubation for $1 \mathrm{~h}$ at $37^{\circ} \mathrm{C}$, a $15-\mu \mathrm{l}$ aliquot from a 10 -fold dilution $(1.5 \mu \mathrm{l}$ of the undiluted suspension) was used to infect monolayers of HeLa cells grown in Dulbecco's modified Eagle's medium (Gibco BRL, Life Technologies, Rockville, Md.) in microtiter plates. At $2 \mathrm{~h}$ postinfection, cytotoxicity was assessed by measurement of released host cell lactate dehydrogenase (LDH) using the CytoTox 96 Non-Radioactive Cytotoxicity Assay (Promega, Madison, Wis.). LDH concentration was measured by reading absorbance at $490 \mathrm{~nm}$ using the microplate analyzer. Relative cytotoxicity calculations were based on the following formula: cytotoxicity percentage $=100 \times\left(A_{\text {sample }}-A_{\text {spontaneous }}\right) /\left(A_{\text {total }}-A_{\text {spontaneous }}\right)$, where $A_{\text {sample }}$ is the absorbance of infected host cells and

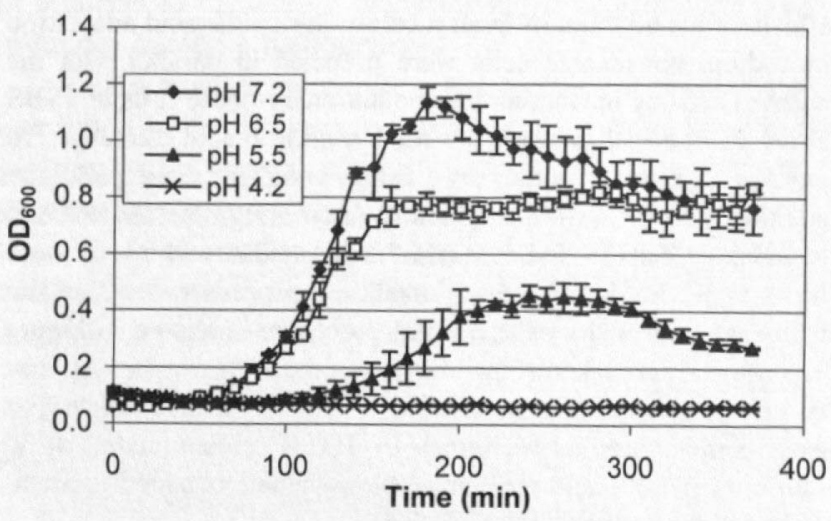

FIGURE 2. Growth of V. parahaemolyticus FSL-Y1-003 in TSBS at $37^{\circ} \mathrm{C}$ at various $\mathrm{pH}$ levels. Error bars represent the SDs from the mean. Experiments were conducted at least in triplicate.
$A_{\text {spontaneous }}$ is the absorbance of uninfected host cells. Cytotoxicity for the internal control (nonadapted $V$. parahaemolyticus FSL-Y1$014)$ was set as $100 \%\left(A_{\text {total }}\right)$ and cytotoxicity for other samples was expressed relative to this control. The cytotoxicity differences between adapted and nonadapted cells were analyzed using the two-sample $t$ test and the Mann-Whitney U test for normally and nonnormally distributed data, respectively (Minitab version 12.0, Minitab, Inc., State College, Pa.).

To ensure that bacterial numbers were similar for all cultures at key points during infection, bacterial cells were counted immediately following infection $(0 \mathrm{~h})$ and at $2 \mathrm{~h}$ postinfection. Nonadapted and adapted cells were present at similar numbers under these conditions for a given isolate (mean \pm standard deviation $[\mathrm{SD}]=0.27 \pm 0.33 \log \mathrm{CFU} / \mathrm{ml})$.

\section{RESULTS}

Acid sensitivity of $\boldsymbol{V}$. parahaemolyticus strains. Initially, growth characteristics at various $\mathrm{pH}$ levels were determined for seven strains (FSL-Y1-003, FSL-Y1-005, FSL-Y1-011, FSL-Y1-013, FSL-Y1-014, FSL-Y1-015, and FSL-Y1-023), which were selected from our collection to represent different serotypes and isolation sources. Overall, growth kinetics were similar for these seven strains. A representative growth curve is illustrated in Figure 2. None of the $V$. parahaemolyticus strains were able to reproduce at $\mathrm{pH}$ 4.2. In these seven strains, $1 \mathrm{~h}$ of exposure at $\mathrm{pH} 4.2$ resulted in mean $( \pm \mathrm{SD})$ reduction of $0.6 \pm 0.5 \log \mathrm{CFU} /$ $\mathrm{ml}$, with a maximum $1.5 \log \mathrm{CFU} / \mathrm{ml}$ reduction (log reduction) in one strain. No colonies were found after $1 \mathrm{~h}$ of exposure at $\mathrm{pH}$ 3.0. Based on these results, we selected exposure to $\mathrm{pH} 3.6$ for $30 \mathrm{~min}$ as the parameters for lethal acid challenge in assays with all $25 \mathrm{~V}$. parahaemolyticus isolates shown in Table 1. Overall, exposure to acid challenge resulted in reductions ranging from 1.9 to $5.4 \mathrm{log}$ 
(a)

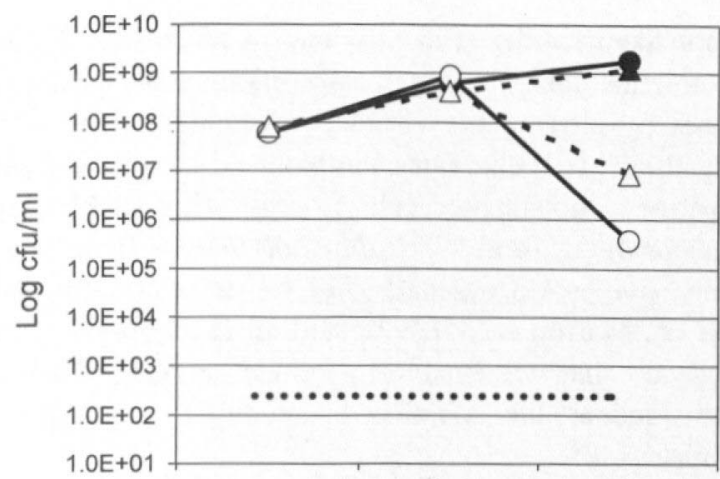

(b)

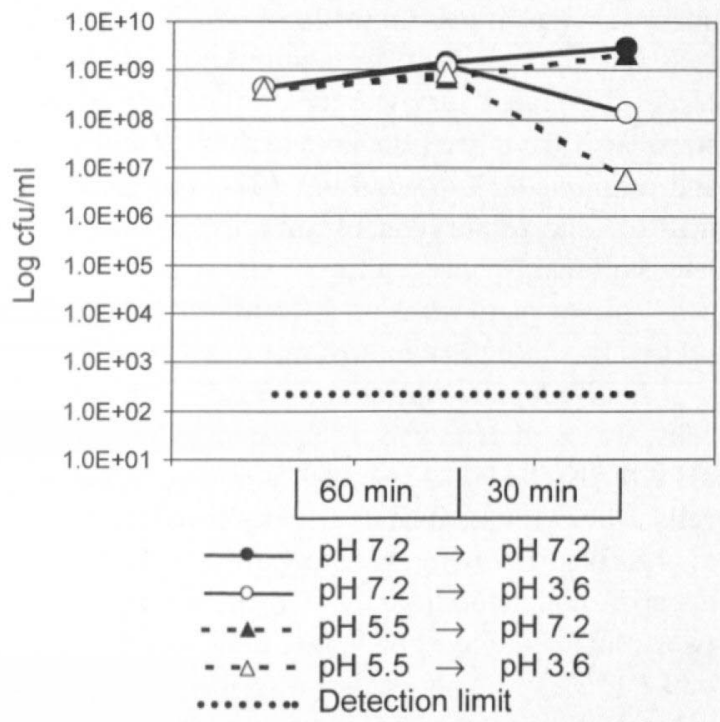

FIGURE 3. Survival of V. parahaemolyticus FSL-Y1-011 following exposure to different $\mathrm{pH}$ levels in one representative experiment. Prior to the experiment, cultures were grown in TSBS until the $O D_{600}$ reached 0.4 to obtain log-phase cells $(a)$ and grown in $T S B S$ until the $O D_{600}$ was $>1.0$ to obtain stationary-phase cells (b).

$\mathrm{CFU} / \mathrm{ml}$ among these stationary-phase cultures. When isolates were categorized by source, $30 \mathrm{~min}$ of $\mathrm{pH} 3.6$ exposure resulted in $3.3 \pm 1.0$ and $3.6 \pm 0.7 \log$ reductions for the clinical and food isolates, respectively. Relative survival of clinical and food isolates did not differ $(P=0.34)$, indicating that the clinical isolates in our collection are not inherently more acid resistant than the food isolates, which had not been associated with foodborne illness.

ATR is induced in log-phase cells. To determine whether the effect of acid adaptation on subsequent survival differed between log-phase and stationary-phase $V$. parahaemolyticus cells, four food isolates (FSL-Y1-001, FSLY1-005, FSL-Y1-006, and FSL-Y1-011) and three clinical isolates (FSL-Y1-013, FSL-Y1-015, and FSL-Y1-017) representing different serotypes were tested. All adapted cells harvested in log phase survived acid challenge more effectively than did nonadapted cells. Conversely, with the exception of FSL-Y1-013, all adapted stationary-phase cells did not survive as well as did their nonadapted counterparts. Representative data are provided in Figure 3, and a data summary from all tested strains is provided in Figure 4. For the seven isolates, mean log reductions for log-phase adapt-

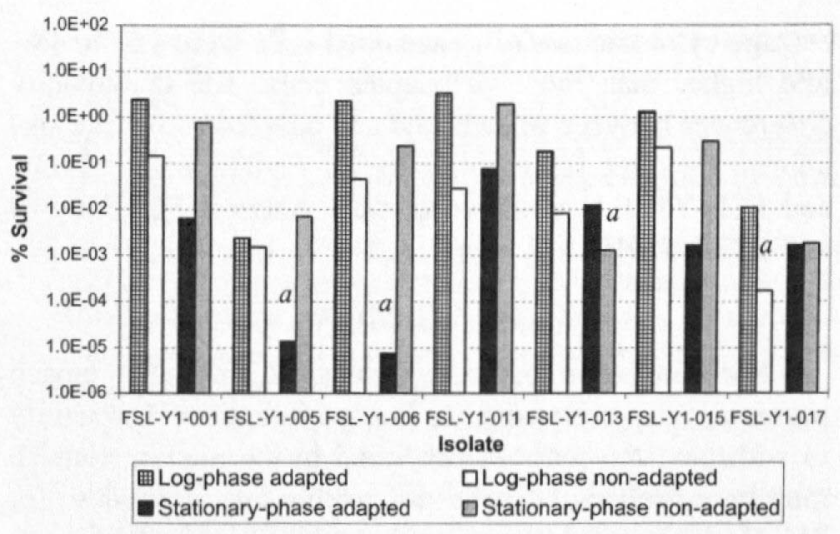

FIGURE 4. Mean relative survival of $\mathrm{V}$. parahaemolyticus following acid challenge (30-min exposure at pH 3.6) in duplicate experiments. Prior to the experiment, cultures were grown until $O D_{600}$ reached 0.4 and $>1.0$ to obtain log-phase and stationaryphase cells, respectively. Nonadapted and adapted cells (columns 2 and 4 in Fig. 1) are those that were preexposed to $\mathrm{pH} 7.2$ and pH 5.5, respectively, for $1 \mathrm{~h}$. For bars labeled a, colony numbers in a single experiment fell below the detection limit of the assay (300 CFU/ml), hence the true survival percentage for these cultures may be lower than that shown.

ed and nonadapted cells were 2.6 and 3.9, respectively. With the exception of FSL-Y1-013, mean log reductions for stationary-phase adapted and nonadapted cells were 5.0 and 3.3, respectively. Survival of stationary-phase $V$. parahaemolyticus FSL-Y1-013 cells differed from that of all other strains. Adapted stationary-phase FSL-Y1-013 cells survived better than did nonadapted cells, with log reductions of 3.9 and 4.9 , respectively.

Virulence-associated characteristics of acid-adapted and nonadapted cells. Host cell LDH release was measured to reflect cytotoxicity resulting from interactions with bacterial pathogens (38). Relative percentage cytotoxicity in HeLa cells ranged from 1.4 to $103.2 \%$ and 6.7 to $133.8 \%$ for adapted and nonadapted cells, respectively (Fig. 5). With the exception of FSL-Y1-013, the mean relative per-

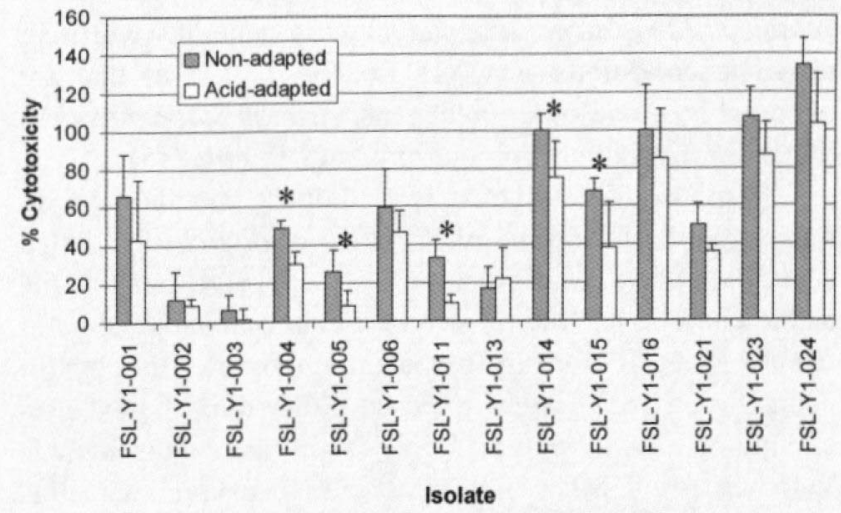

FIGURE 5. Relative cytotoxicity percentage in HeLa cells at $2 \mathrm{~h}$ postinfection for acid-adapted and nonadapted V. parahaemolyticus cultures. Error bars represent the SDs from the mean for at least three independent experiments. An asterisk indicates that the cytotoxicity differences between acid-adapted and nonadapted cells for a given isolate are significantly different $(\mathrm{P}<0.05)$. 
centage cytotoxicities of nonadapted cells were 1.2- to 4.8fold higher than those of adapted cells. The cytotoxicity differences between nonadapted and adapted cells were significant for three food isolates (FSL-Y1-004, FSL-Y1-005, and FSL-Y1-011) and two clinical isolates (FSL-Y1-014 and FSL-Y1-015).

\section{DISCUSSION}

For foodborne pathogens, survival through stomach passage is a prerequisite for human infection. The ability to withstand the reduced $\mathrm{pH}$ found in the human stomach may be correlated with an organism's infectious dose (3, 16,41 ). Therefore, growth or survival capabilities of foodborne pathogens, such as Aeromonas (35), L. monocytogenes (14), Salmonella (4), E. coli (37), Shigella flexneri (40), and Vibrio vulnificus (26), under different acidic conditions represent important areas of study. In a few previous studies, survival of log-phase $V$. parahaemolyticus under acidic conditions has been examined. For example, Wong et al. (43) reported a 1-log reduction for a clinical V. parahaemolyticus strain following $60 \mathrm{~min}$ of exposure to $\mathrm{pH}$ 4.4. Koga et al. (24) reported a 2-log reduction for another

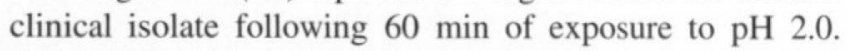
Both groups tested $V$. parahaemolyticus cells that had been harvested in $\log$ phase.

Our data indicate wide variation in acid sensitivities among different $V$. parahaemolyticus strains. Stationaryphase cultures of the $V$. parahaemolyticus isolates in our collection were highly sensitive to $\mathrm{pH} 3.0$. Among the isolates tested, the most and least acid sensitive strains were FSL-Y1-010 and FSL-Y1-014, respectively. These two isolates showed an average of a 5.4- and 1.9-log reduction, respectively, following $30 \mathrm{~min}$ of exposure to $\mathrm{pH} 3.6$. The presence or absence of urease activity could affect the relative acid sensitivities of the $V$. parahaemolyticus strains examined in this study. Urease production can contribute to enhanced acid tolerance in Yersina enterocolitica and Helocobacter pylori $(39,44)$. Therefore, it would be useful to examine the association between urease production and acid tolerance of specific $V$. parahaemolyticus strains. Our findings suggest that, as with Vibrio cholerae (42) and $V$. vulnificus (25), V. parahaemolyticus is generally sensitive to acidic conditions (i.e., pH 3.6 for $\geq 30 \mathrm{~min}$ ) that are tolerated by some other pathogens, such as Staphylococcus aureus, Salmonella Typhimurium, and E. coli (35).

Response to acid stress is a complex phenomenon. In this study, the sensitivity of $V$. parahaemolyticus to a lethal acid challenge was affected by prior exposure to sublethal acidic conditions. Among several foodborne bacterial pathogens, an ATR appears to be an important strategy for counteracting acid stress imposed either during food processing or inside the human host. Many pathogens are able to mount an ATR that enhances bacterial survival of a lethal acid challenge following prior exposure to sublethal acidic conditions $(3,17,32)$. Exposure to sublethal acidic conditions can confer cross protection to other stresses, e.g., heat, osmotic gradients, and bile acid $(24,43)$; therefore, the ability to mount an ATR may provide an organism with relative survival or growth advantages over other microflora that do not have similar acid tolerance mechanisms. Exposure to sublethal acid stress may also influence bacterial pathogenesis by altering the virulence-associated characteristics of acid-adapted cells. For example, acid-adapted cells were superior to nonadapted cells in colonizing suckling mice ( $V$. cholerae (31) and $V$. parahaemolyticus (43)) and were more invasive in Caco-2 and J774.A1 cells ( $L$. monocytogenes (11)). Marron et al. (29) tested an L. monocytogenes LO28 mutant that was unable to induce an ATR and found that this mutant had a reduced capacity to cause infection in mice.

In this study, preexposure to $\mathrm{pH} 5.5$ improved subsequent survival at $\mathrm{pH} 3.6$ for log-phase $V$. parahaemolyticus cells but not in general for stationary-phase cells. Growthphase-dependent survival capabilities following mild acid stress also have been documented for Bacillus cereus (22) and Salmonella Typhimurium (27). For example, in contrast to relative survival of similarly treated lag-, log-, or late stationary-phase cultures, stationary-phase B. cereus cells grown at $\mathrm{pH} 6.0$ or 7.0 showed decreased survival following subsequent exposure to $\mathrm{pH} 4.0$ (22).

Acid-adapted stationary-phase $V$. parahaemolyticus cells, which generally had impaired survival capabilities at pH 3.6, also had decreased cytotoxicity in human epithelial cells. The cytotoxicities of all but one isolate decreased 1.2to 4.8 -fold following preexposure to $\mathrm{pH} 5.5$. Under our experimental conditions, the cytotoxicity differences between adapted and nonadapted cells were significant for 5 of $14(36 \%)$ isolates, suggesting that acid exposure has a substantial negative impact on virulence in some $V$. parahaemolyticus strains. However, as with strain ST550 (43), sublethal acid exposure increased the relative survival and cytotoxicity characteristics of FSL-Y1-013, supporting the hypothesis that mild acid treatment may enhance virulence capabilities for some V. parahaemolyticus strains. However, these data indicate that prior exposure to sublethal acidic conditions does not universally enhance survival and virulence characteristics for $V$. parahaemolyticus under all conditions.

The reduced cytotoxicity of acid-adapted cells could be a consequence of physical injury. $V$. cholerae cells grown at $\mathrm{pH} 6.0$ had reduced expression of various enzymes necessary for lipopolysaccharide biosynthesis, resulting in alterations in the outer membrane and increased susceptibility to hydrophobic drugs (e.g., erythromycin) (18). Acid exposure also represses motility in $V$. cholerae and Salmonella Typhimurium $(1,18)$. Although changes in membrane structure and motility may not necessarily lead to decreased virulence, these findings suggest that significant physiological changes could occur in V. parahaemolyticus following acid exposure.

Apart from the possible intrinsic physiological differences in response to acid stress among strains, the use of different experimental conditions and virulence models may have contributed to variations in observed acid-mediated effects (e.g., survival capabilities and virulence) in previous studies. Experimental variations that influence acid sensitivity include growth phase $(22,27)$, growth medium $(21$, 22 ), growth conditions (12), and type of acid stress (31). 
In addition, bacterial virulence responses may also differ in different hosts. Merrill and Camilli (31) identified a set of genes that are involved in $V$. cholerae acid tolerance in an adult rabbit ligated-loop model. However, fewer than half of these identified genes were induced when $V$. cholerae was inoculated into infant mice. Our results further illustrate the necessity for application of identical experimental conditions to enable direct comparisons of acid tolerances among $V$. parahaemolyticus strains. For example, the protocol used in our ATR experiments (i.e., resuspension of cells in fresh medium with each incubation period) enhanced survival of stationary-phase cells relative to that seen in the acid sensitivity experiments for five of seven $V$. parahaemolyticus strains. The stationary-phase $V$. parahaemolyticus cells used in this study appeared to be more susceptible to acid stress than did the acid-treated log-phase $V$. parahaemolyticus cells used in studies by Koga et al. (24) and Wong et al. (43). Culture growth phase clearly contributes to the experimental outcome of $V$. parahaemolyticus acid tolerance studies.

Estuarine and brackish waters are natural habitats for $V$. parahaemolyticus $(5,6)$. These cells usually experience little variation in environment conditions, i.e., temperatures of 10 to $30^{\circ} \mathrm{C}$, pH of 7 to 8.5 , and salinity of 0.8 to $3 \%(8$, 13). This pathogen has been reported as highly sensitive to heat $\left(55^{\circ} \mathrm{C}\right)$, hydrostatic pressure, and low-temperature pasteurization $(2,7)$. Because $V$. parahaemolyticus is not typically required to survive under extreme ranges of environmental conditions in nature, many strains may lack effective mechanisms for surviving conditions such as acid stress, which can be tolerated by some other foodborne pathogens.

In this study, the majority of $V$. parahaemolyticus strains tested were highly sensitive to a $\mathrm{pH}$ (3.6) that can be tolerated by other major foodborne pathogens (e.g., $E$. coli (35)). Log-phase but not stationary-phase $V$. parahaemolyticus displayed an ATR following exposure to sublethal acidic conditions. Exposure to these conditions impaired subsequent survival and cytotoxicity of stationaryphase cells for all strains except FSL-Y1-013. The recent publication of the $V$. parahaemolyticus genomic sequence (28) will provide the opportunity to use microarrays and proteomics to dissect the complex phenomenon of bacterial behavior following acid exposure and to identify genetic responses important for $V$. parahaemolyticus virulence.

\section{ACKNOWLEDGMENTS}

We are grateful to Martin Wiedmann (Cornell University, Ithaca, N.Y.) for providing intellectual discussions and technical advice and to Angelo DePaola and Charles Kaysner (U.S. Food and Drug Administration, Washington, D.C.) for providing the $V$. parahaemolyticus isolates used in this study. This work was supported by the Cooperative State Research, Education, and Extension Service, National Research Initiative Competitive Grants Program (NRI proposal 2001-35201-10951) of the U.S. Department of Agriculture. P. S. M. Yeung is a recipient of a New York Sea Grant Scholarship (R/SHH-13).

\section{REFERENCES}

1. Adams, P., R. Fowler, N. Kinsella, G. Howell, M. Farris, P. Coote, and C. D. O'Connor. 2001. Proteomic detection of PhoPQ- and acidmediated repression of Salmonella motility. Proteomics 1:597-607.
2. Andrews, L. S., D. L. Park, and Y. P. Chen. 2000. Low temperature pasteurization to reduce the risk of Vibrio infections from raw shellstock oysters. Food Addit. Contam. 17:787-791.

3. Audia, J. P., C. C. Webb, and J. W. Foster. 2001. Breaking through the acid barrier: an orchestrated response to proton stress by enteric bacteria. Int. J. Med. Microbiol. 291:97-106.

4. Bacon, R. T., J. N. Sofos, P. A. Kendall, K. E. Belk, and G. C. Smith. 2003. Comparative analysis of acid resistance between susceptible and multi-antimicrobial-resistant Salmonella strains cultured under stationary-phase acid tolerance-inducing and noninducing conditions. J. Food Prot. 66:732-740.

5. Baross, J., and J. Liston. 1968. Isolation of Vibrio parahaemolyticus from the Northwest Pacific. Nature 217:1263-1264.

6. Baross, J., and J. Liston. 1970. Occurrence of Vibrio parahaemolyticus and related hemolytic vibrios in marine environments of Washington state. Appl. Microbiol. 20:179-186.

7. Berlin, D. L., D. S. Herson, D. T. Hicks, and D. G. Hoover. 1999. Response of pathogenic Vibrio species to high hydrostatic pressure. Appl. Environ. Microbiol. 65:2776-2780.

8. Bhattacharya, M., S. S. Roy, D. Biswas, and R. Kumar. 2000. Effect of $\mathrm{Mg}(2+)$ ion in protein secretion by magnesium-resistant strains of Pseudomonas aeruginosa and Vibrio parahaemolyticus isolated from the coastal water of Haldia Port. FEMS Microbiol. Lett. 185: 151-156,

9. Brudzinski,, L., and M. A. Harrison. 1998. Influence of incubation conditions on survival and acid tolerance response of Escherichia coli $0157: \mathrm{H} 7$ and nonO157:H7 isolates exposed to acetic acid. $J$. Food Prot. 61:542-546.

10. Chowdhury, N. R., S. Chakraborty, T. Ramamurthy, M. Nishibuchi, S. Yamasaki, Y. Takeda, and G. B. Nair. 2000. Molecular evidence of clonal Vibrio parahaemolyticus pandemic strains. Emerg. Infect. Dis. 6:631-636.

11. Conte, M. P., G. Petrone, A. M. Di Biase, M. G. Ammendolia, F. Superti, and L. Seganti. 2000. Acid tolerance in Listeria monocytogenes influences invasiveness of enterocyte-like cells and macrophage-like cells. Microb. Pathog. 29:137-144.

12. Cui, S., J. Meng, and A. A. Bhagwat. 2001. Availability of glutamate and arginine during acid challenge determines cell density-dependent survival phenotype of Escherichia coli strains. Appl. Environ. Microbiol. 67:4914-4918.

13. DePaola, A., C. A. Kaysner, J. Bowers, and D. W. Cook. 2000. Environmental investigations of Vibrio parahaemolyticus in oysters after outbreaks in Washington, Texas, and New York (1997 and 1998). Appl. Environ. Microbiol. 66:4649-4654.

14. Dykes, G. A., and S. M. Moorhead. 2000. Survival of osmotic and acid stress by Listeria monocytogenes strains of clinical or meat origin. Int. J. Food Microbiol. 56:161-166.

15. Gahan, C. G., and C. Hill. 1999. The relationship between acid stress responses and virulence in Salmonella Typhimurium and Listeria monocytogenes. Int. J. Food Microbiol. 50:93-100.

16. Gorden, J., and P. L. C. Small. 1993. Acid resistance in enteric bacteria. Infect. Immun. 61:364-367.

17. Hill, C., B. O'Driscoll, and I. Booth. 1995. Acid adaptation and food poisoning microorganisms. Int. J. Food Microbiol. 28:245-254.

18. Hommais, F, C. Laurent-Winter, V. Labas, E. Krin, C. Tendeng, O. Soutourina, A. Danchin, and P. Bertin. 2002. Effect of mild acid pH on the functioning of bacterial membranes in Vibrio cholerae. Proteomics 2:571-579.

19. Honda, S., I. Goto, I. Minematsu, N. Ikeda, N. Asano, M. Ishibachi, Y. Kinoshita, M. Nishibuchi, T. Honda, and T. Miwatani. 1987. Gastroenteritis due to Kanagawa negative Vibrio parahaemolyticus. Lancet $\mathrm{i}: 331-332$.

20. Honda, T., Y. Ni, and T. Miwatani. 1988. Purification and characterization of a hemolysin produced by a clinical isolate of Kanagawa phenomenon-negative Vibro parahaemolyticus and related to the thermostable direct hemolysin. Infect. Immun. 56:961-965.

21. Jarvis, G. N., and J. B. Russell. 2001. Differences in Escherichia coli culture conditions can have a large impact on the induction of extreme acid resistance. Curr. Microbiol. 43:215-219.

22. Jobin, M.-P., T. Clavel, F. Carlin, and P. Schmitt. 2002. Acid tolerance 
response is low-pH and late-stationary growth phase inducible in Bacillus cereus TZ415. Int. J. Food Microbiol. 79:65-73.

23. Kaysner, C. A., C. Abeyta, Jr., P. A. Trost, J. H. Wetherington, K. C. Jinneman, W. E. Hill, and M. M. Wekell. 1994. Urea hydrolysis can predict the potential pathogenicity of Vibrio parahaemolyticus strains isolated in the Pacific Northwest. Appl. Environ. Microbiol. 60:3020-3022.

24. Koga, T., F. Sakamoto, A. Yamoto, and K. Takumi. 1999. Acid adaptation induces cross-protection against some environmental stresses in Vibrio parahaemolyticus. J. Gen. Appl. Microbiol. 45:155-161.

25. Koo, J., A. DePaola, and D. L. Marshall. 2000. Effect of simulated gastric fluid and bile on survival of Vibrio vulnificus and Vibrio vulnificus phage. J. Food Prot. 63:1665-1669.

26. Koo, J., D. L. Marshall, and A. DePaola. 2001. Antacid increases survival of Vibrio vulnificus and Vibrio vulnificus phage in a gastrointestinal model. Appl. Environ. Microbiol. 67:2895-2902.

27. Lee, I. S., J. L. Slonczewski, and J. W. Foster. 1994. A low-pHinducible, stationary-phase acid tolerance response in Salmonella Typhimurium. J. Bacteriol. 176:1422-1426.

28. Makino, K., K. Oshima, K. Kurokawa, K. Yokoyama, T. Uda, K. Tagomori, Y. Iijima, M. Najima, M. Nakano, A. Yamashita, Y. Kubota, S. Kimura, T. Yasunaga, T. Honda, H. Shinagawa, M. Hattori, and T. Iida. 2003. Genome sequence of Vibrio parahaemolyticus: a pathogenic mechanism distinct from that of $V$. cholerae. Lancet 361 : 743-749.

29. Marron, L., N. Emerson, C. G. Gahan, and C. Hill. 1997. A mutant of Listeria monocytogenes LO28 unable to induce an acid tolerance response displays diminished virulence in a murine model. Appl. Environ. Microbiol. 63:4945-4947.

30. Matsumoto, C., J. Okuda, M. Ishibashi, M. Iwanaga, P. Garg, T. Rammamurthy, H. C. Wong, A. DePaola, Y. B. Kim, M. J. Albert, and M. Nishibuchi. 2000. Pandemic spread of an O3:K6 clone of Vibrio parahaemolyticus and emergence of related strains evidenced by arbitrarily primed PCR and toxRS sequence analyses. J. Clin. Microbiol. 38:578-585.

31. Merrell, D. S., and A. Camilli. 1999. The cadA gene of Vibrio cholerae is induced during infection and plays a role in acid tolerance. Mol. Microbiol. 34:836-849.

32. Merrell, D. S., and A. Camilli. 2002. Acid tolerance of gastrointestinal pathogens. Curr. Opin. Microbiol. 5:51-55.

33. Miyamoto, Y., T. Kato, Y. Obara, S. Akiyama, K. Takizawa, and S.
Yamai. 1969. In vitro hemolytic characteristics of Vibrio parahaemolyticus: its close correlation with human pathogenicity. J. Bacteriol. 100:1147-1149.

34. Nishibuchi, M., A. Fasano, R. G. Russell, and J. B. Kaper. 1992. Enterotoxigenicity of Vibrio parahaemolyticus with and without genes encoding thermostable direct hemolysin. Infect. Immun. 60: 3539-3545,

35. Nishikawa, Y., J. Ogasawara, and T. Kimura. 1993. Heat and acid sensitivity of motile Aeromonas: a comparison with other food-poisoning bacteria. Int. J. Food Microbiol. 18:271-278.

36. O'Driscoll, B., C. G. Gahan, and C. Hill. 1996. Adaptive acid tolerance response in Listeria monocytogenes: isolation of an acid-tolerant mutant which demonstrates increased virulence. Appl. Environ. Microbiol, 62:1693-1698.

37. Paul, B., and I. Hirshfield. 2003. The effect of acid treatment on survival and protein expression of a laboratory K-12 strain Escherichia coli. Res. Microbiol, 154:115-121.

38. Raimondi, F, J. P. Kao, C. Fiorentini, A. Fabbri, G. Donelli, N. Gasparini, A. Rubino, and A. Fasano. 2000. Enterotoxicity and cytotoxicity of Vibrio parahaemolyticus thermostable direct hemolysin in in vitro systems. Infect. Immun. 68:3180-3185.

39. Scott, D. R., E. A. Marcus, D. L. Weeks, and G. Sachs. 2002. Mechanisms of acid resistance due to the urease system of Helicobacter pylori. Gastroenterology 123:187-195.

40. Tetteh, G. L., and L. R. Beuchat. 2003. Survival, growth, and inactivation of acid-stressed Shigella flexneri as affected by $\mathrm{pH}$ and temperature. Int. J. Food Microbiol. 87:131-138.

41. Waterman, S. R., and P. L. Small. 1996. Identification of sigma Sdependent genes associated with the stationary-phase acid-resistance phenotype of Shigella flexneri. Mol. Microbiol. 21:925-940.

42. Waterman, S. R., and P. L. C. Small. 1998. Acid-sensitive enteric pathogens are protected from killing under extremely acidic conditions of $\mathrm{pH} 2.5$ when they are inoculated onto certain solid food sources. Appl. Environ. Microbiol. 64:3882-3886.

43. Wong, H. C., P. Y. Peng, J. M. Han, C. Y. Chang, and S. L. Lan. 1998. Effect of mild acid treatment on the survival, enteropathogenicity, and protein production in Vibrio parahaemolyticus. Infect. Immun. 66:3066-3071.

44. Young, G. M., D. Amid, and V. L. Miller. 1996. A bifunctional urease enhances survival of pathogenic Yersinia enterocolitica and Morganella morganii at low pH. J. Bacteriol. 178:6487-6495. 